\title{
Influences of long-term changes in land cover on mammal populations: an example from Mexico
}

\author{
Consuelo Lorenzo, Eugenia C. Sántiz \\ Jorge Bolaños-Citalán and Darío Navarrete-Gutiérrez
}

\begin{abstract}
Changes in vegetative cover and land use in the southern part of the Isthmus of Tehuantepec in Oaxaca, Mexico, were identified by analysing satellite images from 2001 and 2014. Fluctuations in population density of mammal species during 2001-2016 in response to these changes were analysed. During 2001-2014 the types of land use that increased in area (per year) were prescribed burning (uncontrolled burning caused by humans) by 105.11 ha, seasonal agricultural plots by 58.14 ha, areas without vegetation by $24.54 \mathrm{ha}$, and human settlements by $4.13 \mathrm{ha}$. In the same period, savannahs decreased by 103.94 ha, tropical dry forest by 39.5 ha, secondary forests by $14.46 \mathrm{ha}$, and humaninduced grassland by 0.13 ha per year. The loss of these habitats resulted in low population densities of mammals, including the eastern cottontail Sylvilagus floridanus and the Tehuantepec jackrabbit Lepus flavigularis, which is categorized as Endangered on the IUCN Red List. We recommend establishing a communal ecological reserve in the study area to implement appropriate management strategies for grassland communities and develop a programme of semi-captive breeding to conserve $L$. flavigularis.
\end{abstract}

Keywords Carnivores, conservation, land management, land use, Lepus flavigularis, Oaxaca, population density, Sylvilagus floridanus

\section{Introduction}

$\mathrm{n}$ tropical regions changes in land use have been the main 1 cause of biodiversity loss, with the associated loss of habitats for wild flora and fauna (Arriaga \& Gómez, 2004; González et al., 2004; INEGI, 2005). The principal causes of changes in vegetative cover and land use on the Isthmus of Tehuantepec in Oaxaca, Mexico, are human population

Consuelo Lorenzo (Corresponding author), Eugenia C. SÁntiz and Jorge Bolaños-Citalán Departamento de Conservación de la Biodiversidad, El Colegio de La Frontera Sur, Unidad San Cristóbal, Carretera Panamericana y Periférico Sur s/n, Barrio de María Auxiliadora, C.P. 29290, San Cristóbal de Las Casas, Chiapas, México. E-mail clorenzo@ecosur.mx

Darío NAVARRete-GutiéRrez Laboratorio de Información Geográfica, El Colegio de La Frontera Sur, Unidad San Cristóbal, San Cristóbal de Las Casas, Chiapas, México

Received 31 August 2016. Revision requested 24 February 2017.

Accepted 3 April 2017. First published online 27 June 2017. growth (Mas et al., 2009; Nájera et al., 2010), which increases demand for space for housing and food production, and poor agricultural management, particularly with respect to livestock raising and prescribed burning of pastures (uncontrolled burning of grasses to promote new growth of grazing pasture for cattle) for seasonal crops (López-Granados et al., 2002; Peralta-Rivero et al., 2014). Both of these matters have led to reduction, degradation and fragmentation of habitat (Bender et al., 1998; Rioja et al., 2011; Lorenzo et al., 2014), directly affecting the amount and quality of vegetation, as well as food availability for wild animals.

In the southern region of the Isthmus of Tehuantepec, habitat consists of scrub and mangrove, with submerged vegetation in coastal lagoons (Superior Lagoon and Inferior Lagoon; Ortiz et al., 2004), as well as extensive areas of savannah with isolated shrubs and trees (Rzedowski, 2006; Sántiz et al., 2012). Large areas of low tropical deciduous and low deciduous forest (Torres-Colín, 2004), as well as savannahs and human-induced grasslands (native or exotic species that develop in sites in which the original vegetation has been eliminated or in abandoned agricultural areas; Aristida, Bouteloua, Cathestecum, Cenchrus, Digitaria, Eragrostis, Panicum, Paspalum and Schizachyrium) are found in this region (Rzedowski, 2006; INEGI, 2012; Sántiz et al., 2012).

Grasslands of the Isthmus of Tehuantepec have been transformed for agriculture and livestock raising, causing degradation and reduction of the original vegetation (Sántiz et al., 2016). One mammal species of the region that depends on savannahs and human-induced grasslands is the endemic Tehuantepec jackrabbit Lepus flavigularis (Anderson \& Gaunt, 1962; Lorenzo et al., 2000), which is categorized as Endangered on the IUCN Red List (Cervantes et al., 2008). This lagomorph shares its habitat with other lagomorphs, such as the eastern cottontail Sylvilagus floridanus, as well as their predators: the coyote Canis latrans and the grey fox Urocyon cinereoargenteus (Lorenzo et al., 2000; López et al., 2009).

Interactions among taxa influence abundance and density (Erlinge et al., 1984; Daniel et al., 1993; Bailey, 2005) and can cause population fluctuations in response to environmental changes and the amount and quality of available food (Keith \& Windberg, 1978; Keith, 1990). Therefore, identifying the impact of changes in vegetative cover and land use on distribution and population fluctuations of mammals, using basic ecological parameters such as population abundance and density, facilitates decision making 
for the conservation of endemic and threatened mammal species, such as L. flavigularis, as well as adequate management of agriculture and other land-based economic activities.

Densities of 6-13 individuals $\mathrm{km}^{-2}$ have been reported for L. flavigularis (Lorenzo et al., 2000; Vargas, 2000; Sántiz, 2002), and abrupt changes in density have been recorded over 6 years of monitoring. These changes have been partially attributed to management practices such as prescribed burning and grazing (Lorenzo et al., 2008).

Given the importance for wildlife management and conservation of identifying long-term fluctuations in the population density of lagomorphs, the relationship of these fluctuations to those of carnivores, and the responses of lagomorph population densities to changes in vegetative cover and land use (such as grazing and prescribed burning), the objective of this study was to examine the relationships between fluctuations in population densities of mammals (L. flavigularis, S. floridanus, and their natural predators $U$. cinereoargenteus and $C$. latrans) and changes in land use and vegetative cover over a 16-year period.

\section{Study area}

Land use and vegetative cover were analysed in four municipalities in the southern region of the Isthmus of Tehuantepec in the Mexican state of Oaxaca: San Francisco del Mar, San Francisco Ixhuatán, San Dionisio del Mar, and Juchitán de Zaragoza. Mammals were monitored in Montecillo Santa Cruz in the municipality of San Francisco del Mar, and Huamuchil in the municipality of San Dionisio del Mar (Fig. 1). The study area comprised $33.1 \mathrm{~km}^{2}$ and the area surveyed for mammals was $1.6 \mathrm{~km}^{2}$. Climate is warm sub-humid, with a mean annual temperature of $25^{\circ} \mathrm{C}$, and mean total annual precipitation of $932.2 \mathrm{~mm}$ (García, 1988).

Residents of Montecillo Santa Cruz are traditional fishers, although over the past decade they have begun to plant sorghum for sale and use as fodder for livestock, and maize and watermelon for family consumption (Vargas, 2001; Sántiz et al., 2012). Cattle are raised extensively in all grassland areas, and prescribed burning is carried out to promote regeneration of grasses (Lorenzo et al., 2000, 2008; Vargas, 2000).

Within the study area a sand bar connects the Inferior Lagoon with the Gulf of Tehuantepec (Fig. 1). The sand bar closes and opens cyclically, changing in length as a result of natural events (e.g. changes in sea level, hurricanes). This process affects local people's socio-economic activities, as they principally engage in fishing. When the sand bar is closed, movement of fish and nutrients from the Gulf of Tehuantepec to the Inferior Lagoon is inhibited, and fish and shrimp populations decrease, and therefore local people turn to subsistence hunting, which has a negative effect on populations of lagomorphs, mainly L. flavigularis. Grey foxes and coyotes are also hunted, although not on a regular basis (J. Antonio, pers. comm.).

\section{Methods}

\section{Surveys}

The population density of L. flavigularis, S. floridanus and the carnivores $U$. cinereoargenteus and $C$. latrans was estimated annually during at least 1 month in the dry season (November-April) and 1 month in the rainy season (May-October) over 16 years (2001-2016). As there were few sightings of $U$. cinereoargenteus and $C$. latrans, these were grouped together as carnivores. We used the line transect method (Buckland et al., 2015) to monitor mammal species along an $8 \mathrm{~km}$ transect of variable width between Montecillo Santa Cruz and Huamuchil. This transect was established according to accessibility (traversable roads) and visibility (flat open areas) (Fig. 1). Number of individuals was recorded while travelling along the transect in a pickup truck at 5-10 km per hour, at night, using halogen lanterns for illumination. Geographical location, altitude, habitat type, and perpendicular distance (the shortest distance from the individual to the transect, in $\mathrm{m}$; Buckland et al., 2015) were recorded for each individual observed. The perpendicular distance was recorded for jackrabbits and cottontail rabbits since 2001, and for carnivores since 2003. For this, an electronic distance measuring device (Bushnell Yardage Pro, Bushnell Corporation, Overland Park, USA) was used. All surveys were conducted during 20.00-02.00, when lagomorphs and carnivores are most active (Carrillo-Reyes et al., 2010; Rioja et al., 2011). Each night, the same $8 \mathrm{~km}$ transect was travelled in both directions, at least 2 hours apart to avoid duplicating data (in number of records and kilometers travelled); each mammal observed was recorded, and density was estimated using these data.

Data were analysed using Distance 6.o (Buckland et al., 2015) to estimate density for each mammal species, and we considered each direction travelled along the transect to be independent (i.e. we analysed the data for each direction independently). To evaluate the probability of detecting animals, the four models used by Distance were tested: halfnormal, uniform, hazard rate, and negative exponential. Each model varies depending on homogeneity of sightings, probability of detecting individuals according to the distance from which they are observed, and number of sightings (Buckland et al., 2015). In each case a cosine adjustment was assessed using likelihood ratio tests. The longest $5 \%$ of the perpendicular distances recorded throughout the analyses were eliminated to avoid bias introduced by atypical outlier distance sightings. The final model was 


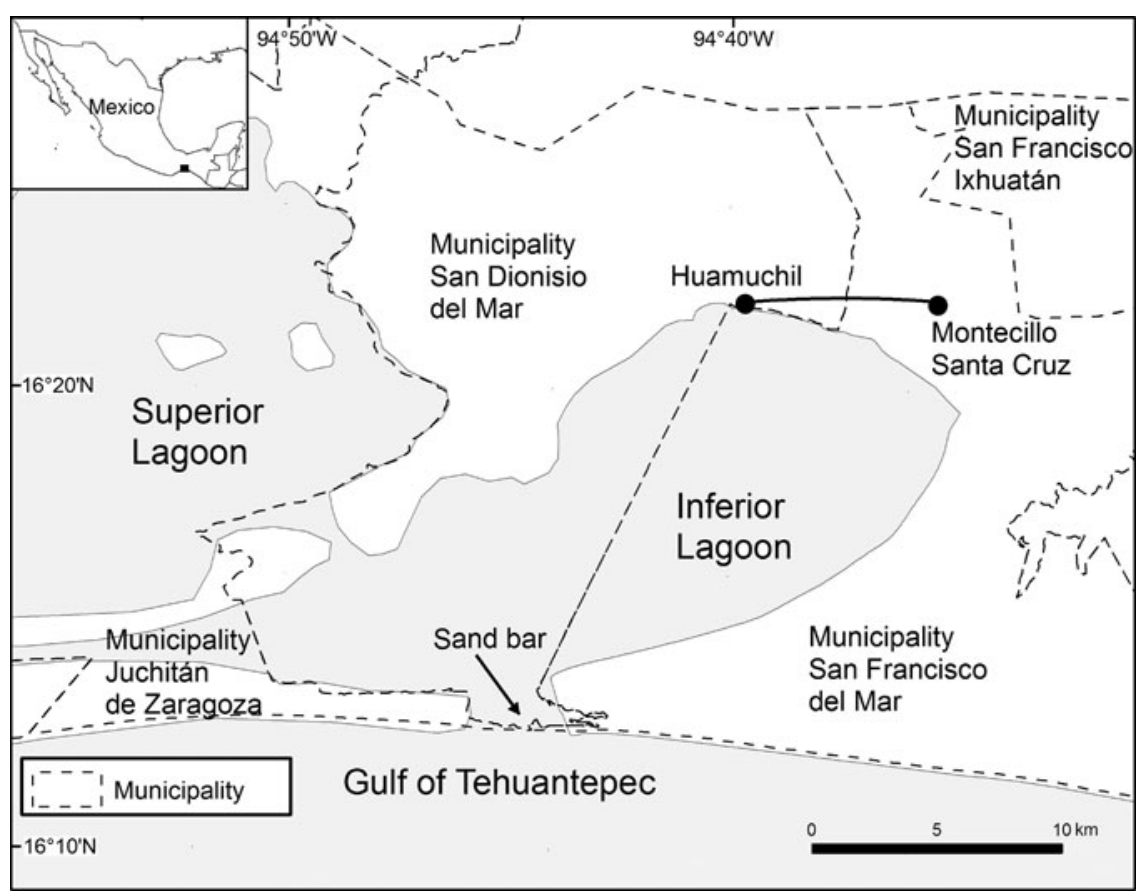

FIg. 1 Study area in Montecillo Santa Cruz, south-eastern Oaxaca, Mexico, in which vegetative cover and land use were analysed, with the location of an $8 \mathrm{~km}$ transect between Montecillo and Huamuchil along which lagomorphs and carnivores were monitored during 20012016. chosen based on a combination of the lowest value for Akaike's information criterion (AIC) and the lowest variance (Rizo-Aguilar et al., 2016) for each year of monitoring. The population density obtained corresponds to the area monitored for mammals $\left(1.6 \mathrm{~km}^{2}\right.$; i.e. the length of the transect $(8 \mathrm{~km})$ multiplied by the maximum perpendicular distance (100 $\mathrm{m}$ each side of the transect) at which it is possible to identify observed animals). The results obtained for the density in the monitoring area $\left(1.6 \mathrm{~km}^{2}\right)$ were extrapolated to the total study area $\left(33.1 \mathrm{~km}^{2}\right)$.

\section{Changes in vegetative cover and land use}

Maps of vegetation and land use were created using analysis of a 2001 satellite image, from the Landsat Enhanced Thematic Mapper (ETM+), and a 2014 image from the Landsat Operational Land Imager (OLI). Changes in vegetative cover and land use were processed using the interdependent classification method (FAO, 1996), stratifying the two scenes with ArcGIS 10.2 (ESRI, Redlands, USA). Using this approach we delimited polygons for each type of vegetation and land use, to avoid bias in delimiting each thematic class. Estimating changes in surface area also involved the road layer, taken from a 2012 base map, using ArcGis 10.2, and the digital elevation model of Instituto Nacional de Estadística y Geografía (for 2013, with $30 \mathrm{~m}$ resolution).

To verify classification of the satellite image and ensure reliability of vegetative cover and land-use maps, 130 control points were recorded using a global positioning system in sites where the vegetation could potentially be interpreted

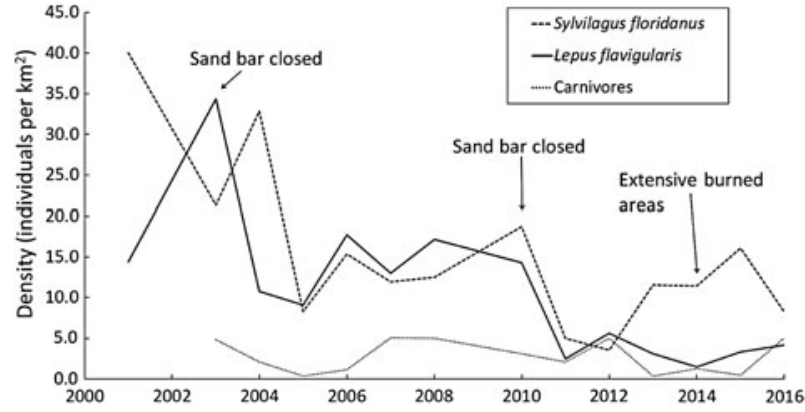

FIg. 2 Fluctuations in population densities of the Tehuantepec jackrabbit Lepus flavigularis, the eastern cottontail Sylvilagus floridanus, and carnivores (Canis latrans and Urocyon cinereoargenteus) in Montecillo Santa Cruz, Municipality San Francisco del Mar, and Huamuchil, Municipality San Dionisio del Mar, Oaxaca, Mexico (Fig. 1) during 2001-2016, with years indicated in which the sand bar was closed and in which there was extensive burning.

correctly or incorrectly from satellite images (Velázquez et al., 2002). For these points, types of vegetation and land use were described.

Once vegetation and land-use maps were drawn up for 2001 and 2014, along with the road layer and the digital elevation model, rates of change were estimated using the transition matrices (Bocco et al., 2001) by superimposing maps using the Land Change Modeler module of IDRISI Selva v. 17.02 (Clark Labs, Worcester, USA). An equation proposed by the FAO (1996) was used to obtain rates of percentage change in surface area for each type of vegetation and land use. This procedure was applied to all types of vegetation and land use: human-induced grassland, savannah, 
TABle 1 Percentage change $(\delta)$ in surface area (ha) for each type of vegetation and land use in Montecillo Santa Cruz, Oaxaca, Mexico (Fig. 1), in 2001 and 2014, with the change in area (ha), the percentage lost or gained, and the change per year (ha).

\begin{tabular}{|c|c|c|c|c|c|c|}
\hline \multirow{2}{*}{$\begin{array}{l}\text { Types of vegetative cover and } \\
\text { land use }\end{array}$} & \multicolumn{2}{|c|}{ Surface area (ha) } & \multirow[b]{2}{*}{$\delta(\%)$} & \multirow{2}{*}{$\begin{array}{l}\text { Change in } \\
\text { area (ha) }\end{array}$} & \multirow{2}{*}{$\begin{array}{l}\% \text { loss } \\
\text { or gain }\end{array}$} & \multirow{2}{*}{$\begin{array}{l}\text { Change per } \\
\text { year (ha) }\end{array}$} \\
\hline & 2001 & 2014 & & & & \\
\hline Human-induced grassland & $6,806.5$ & $6,804.8$ & -0.002 & -1.710 & -0.03 & -0.13 \\
\hline Savannah & $8,174.5$ & $6,823.4$ & -1.4 & -1351.2 & -16.5 & -103.94 \\
\hline Seasonal agriculture & $3,087.1$ & $3,842.9$ & 1.8 & 755.8 & 24.5 & 58.14 \\
\hline Human settlements & 202.1 & 255.9 & 1.9 & 53.7 & 26.6 & 4.13 \\
\hline Tropical dry forest & $6,474.9$ & $5,961.4$ & -0.7 & -513.5 & -7.9 & -39.50 \\
\hline Burned area & 957.2 & $2,323.5$ & 7.4 & 1366.4 & 142.8 & 105.11 \\
\hline Areas without vegetation & 833.7 & $1,152.7$ & 7.4 & 319.1 & 38.3 & 24.54 \\
\hline Secondary forest & $5,721.8$ & $5,533.8$ & 2.6 & -187.9 & -3.3 & -14.46 \\
\hline Bodies of water & $28,895.2$ & $28,531.4$ & -0.3 & -363.8 & -1.3 & -27.98 \\
\hline Mangrove swamp & 3,399.9 & $3,323.0$ & -0.1 & -76.9 & -2.3 & -5.92 \\
\hline
\end{tabular}

seasonal agriculture, human settlements, tropical dry forest, burned areas, areas without vegetation, secondary forest, bodies of water, and mangrove swamps. The results describe transitions from one type of land cover to another throughout the region (Velázquez et al., 2002).

\section{Results}

In Montecillo Santa Cruz the mean estimated density of L. flavigularis during 2001-2016 was 9.14 \pm SE 0.79 individuals per $\mathrm{km}^{2}$ (range 1.44-34.37; model hazard rate/ cosine; $\mathrm{AIC}=5375.7 ; \mathrm{CV}=8.65 \%)$ and of $S$. floridanus $12.28 \pm$ SE 1.49 individuals per $\mathrm{km}^{2}$ (range 3.57-40.01; model hazard rate/cosine; $\mathrm{AIC}=2164.9 ; \mathrm{CV}=12.12 \%)$. The mean estimated density of the carnivores $U$. cinereoargenteus and $C$. latrans during 2003-2016 was $1.91 \pm \mathrm{SE} 0.40$ individuals per $\mathrm{km}^{2}$ (range 0.35-5.06; model hazard rate/cosine; $\mathrm{AIC}=599.94$; $\mathrm{CV}=23.5 \%$ ). The total sampling effort (for all 16 years) was $568 \mathrm{~km}$ travelled for L. flavigularis and S. floridanus, and $472 \mathrm{~km}$ travelled for the carnivores.

Fluctuations in mean annual population density for each mammal species/group are shown in Fig. 2. Although several fluctuations occurred during 2001-2016, as a general trend the density of L. flavigularis indicates a general decline; Sylvilagus floridanus has also declined but appears to be stable since 2005; and carnivores tended towards stability throughout the study period (Fig. 2).

Savannah $(8,174.5$ ha in $2001 ; 6,823.4$ ha in 2014$)$ and human-induced grassland $(6,806.5$ ha in $2001 ; 6,804.8$ ha in 2014) were the dominant cover types in the study area (Table 1), accounting for 11.6 and $10.5 \%$ of total surface area on average, respectively. Almost all vegetative cover types showed losses in surface area from 2001 to 2014, but the most drastic loss occurred in savannah, with a $1.4 \%$ decrease annually, and a total loss of $1,351.2$ ha (16.5\%) of the original surface area. This was principally a result of fires (burned area $=1,024.1 \mathrm{ha}$ ) and an increase in agricultural areas (302 ha). Tropical dry forest lost 513.4 ha (7.9\%), with an annual loss of $0.7 \%$, and an increase in human-induced grassland (238.8 ha) and burned areas (190.9 ha; Table 2).

From 2001 to 2014 seasonal agriculture, human settlements, burned areas and areas without vegetation showed annual increases in surface area. Burned areas increased by $7.4 \%$ annually, with a total increase of $1,366.4$ ha (142.8\%). During the same time period, areas without vegetation increased by $7.4 \%$ annually, with a total increase of 319.1 ha $(38.3 \%$; Table 1$)$. Burned areas were located mainly in savannahs $(1,024.1 \mathrm{ha})$, human-induced grasslands (286 ha), and forests (190.9 ha; Table 2). All changes (losses and increases) in land use and surface area of vegetative cover from 2001 to 2014 are shown in Fig. 3.

\section{Discussion}

The estimated population density of L. flavigularis (9.14 individuals $\mathrm{km}^{-2}$ ) in the study region is similar to estimates from previous studies (1.3-11.5 individuals $\mathrm{km}^{-2}$; Vargas, 2000; Sántiz, 2002; Lorenzo et al., 2008). However, mean densities of L. flavigularis are low compared to other lagomorph species, such as Lepus californicus (20-154 individuals $\mathrm{km}^{-2}$; Hayden, 1966; Davis \& Schmidly, 1997; Portales-Betancourt et al., 2012). The estimated population density for $S$. floridanus in this study (12.28 individuals $\mathrm{km}^{-2}$ ) is also low compared to other studies of the same species (27.5-2,000 individuals $\mathrm{km}^{-2}$; Chapman et al., 1982; Silvano et al., 2000). Alteration and degradation of lagomorph habitat has probably led to a decrease in available food and space over time, resulting in lower population densities (Lorenzo et al., 2000; Sántiz, 2002).

The density of L. flavigularis decreased drastically over the study period, whereas the density of S. floridanus decreased significantly only during 2001-2005. Highs and lows in densities of the two species (Fig. 2) did not overlap except in 2005-2007 and 2011; this may be explained by the differential response of the two species to habitat use and 


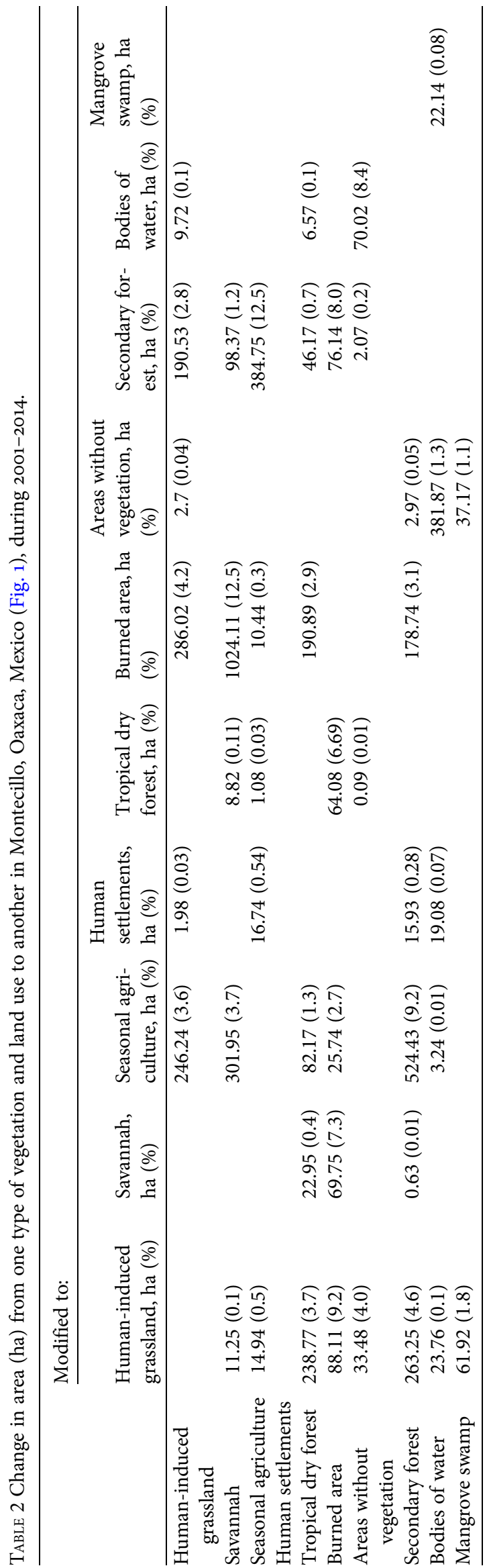

food availability. Lepus flavigularis inhabits savannahs and human-induced grasslands (Lorenzo et al., 2006; Carrillo-Reyes et al., 2010; Sántiz et al., 2012) and feeds mainly on grasses (Lorenzo et al., 2011), whereas S. floridanus inhabits human-induced grasslands, tropical forests, and scrub-brush, feeding on herbaceous and woody plants (Chapman et al., 1980; Chapman \& Ceballos, 1990). It is likely that the two species avoid competing with each other.

The combined population density of the carnivores $U$. cinereoargenteus and C. latrans was stable over time. These species are adapted to a range of environments and can travel long distances in search of food, without excessive energy expenditure (Villa \& Cervantes, 2003). In our study area, at least, they do not appear to be greatly affected by changes in land cover.

In the study area, burned areas, areas without vegetation, and human settlements increased in surface area from 2001 to 2014. Undisturbed land has been converted to agriculture, with an increase in surface area of 755.8 ha during this period. This land was initially planted with corn; however, as a result of changes in geographical and environmental conditions (sandy soil, drought and intense rainfall), cultivation of sorghum has increased since 2005 (Vargas, 2001; Lorenzo et al., 2006; Rioja-Paradela et al., 2012).

Savannahs and forests have increasingly been converted to pastures for livestock raising (Lorenzo et al., 2006; Rioja-Paradela et al., 2012), affecting the coverage and diversity of vegetation (Altesor et al., 2005). Trampling by cattle modifies the soil's physical properties, causing it to lose its capacity for water retention, thereby facilitating erosion (Drewry \& Paton, 2000). It has been observed that the permanence of the height and cover of species of bunchgrass such as Muhlenbergia macroura and Jarava ichu benefits the presence and abundance of other threatened lagomorph species, such as the volcano rabbit Romerolagus diazi, because it provides refuge from potential predators and nesting (Hoth et al., 1987; Rizo-Aguilar et al., 2015).

To manage grazing areas, residents of Montecillo Santa Cruz carry out prescribed burning, which consists of deliberately causing fires to promote regeneration of grasslands during the dry season. However, these fires frequently become uncontrolled, affecting large areas of land (Lorenzo et al., 2000, 2008; Vargas, 2000).

Changes in land use to accommodate agriculture, including prescribed burning, have been the main cause of destruction of large areas of savannah (16.5\% of the original surface area), which is the preferred habitat of $L$. flavigularis. This is a significant threat to this Endangered species, as lagomorphs are unable to quickly recolonize intensively burned areas (Meslow \& Keith, 1968; Driessen, 1999; Salvatori et al., 2001). The time it takes for lagomorphs to recolonize these areas depends on how long it takes for habitat to recover its capacity to provide them with sufficient food and protection (Parker, 1984), and burning results in 


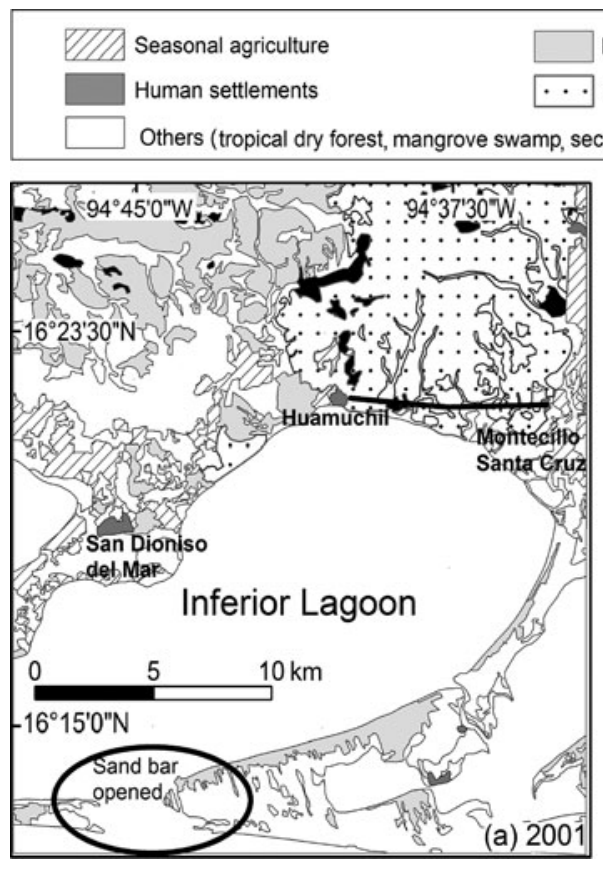

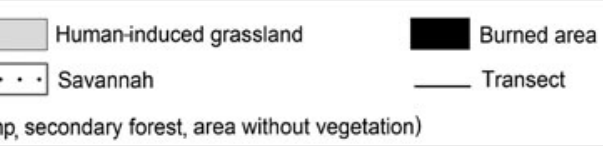

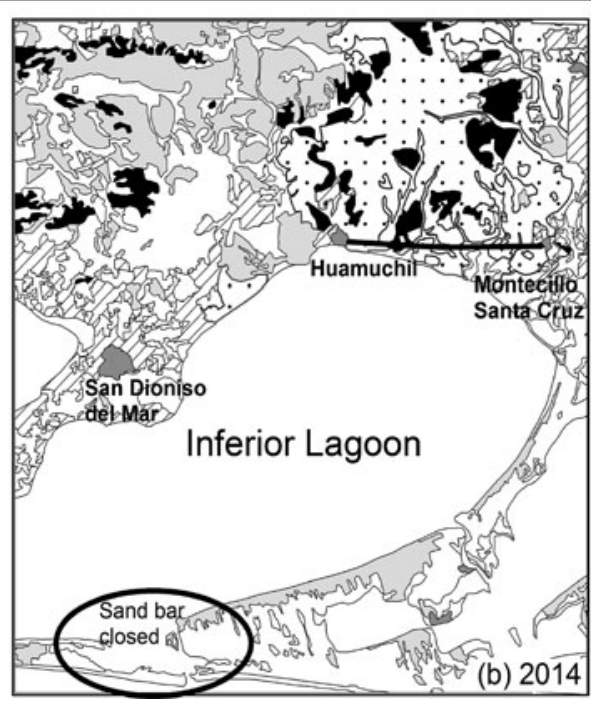

FIG. 3 Vegetative cover and land use in the municipalities of San Dionisio del Mar, San Francisco del Mar, San Francisco Ixhuatán, and Juchitán de Zaragoza, Oaxaca, Mexico, in (a) 2001 and (b) 2014. temporary habitat fragmentation, which could affect population densities of several species (Fahrig \& Paloheimo, 1988; Diffendorfer et al., 1995; Klok \& De Roos, 1998). Our findings support this observation, as the population density of L. flavigularis decreased in 2014, when burned areas increased (Fig. 2). However, fires have had a positive effect on the abundance of $R$. diazi, as they maintain and promote new growth of the dominant zacaton bunchgrass, the main food source for this rabbit (Hunter \& Cresswell, 2015). Additionally, the closing of the sand bar affects lagomorph population density. The sand bar closed in 2003 and 2010, and the following years the mean population density of L. flavigularis decreased (from 34.4 individuals $\mathrm{km}^{-2}$ in 2003 to 10.8 individuals $\mathrm{km}^{-2}$ in 2004 , and from 17.2 individuals $\mathrm{km}^{-2}$ in 2008 to 2.5 individuals $\mathrm{km}^{-2}$ in 2011). This process appears to be affecting survival of the species, although the sand bar remained open in 2015 and 2016 and the population recovered slightly.

\section{Conservation and management strategies}

We offer several recommendations to conserve L. flavigularis and establish appropriate management strategies for grassland and savannah communities. (1) Grasses should be controlled annually by fire, taking care that fire does not spread beyond targeted areas. (2) Livestock-raising practices should be improved to avoid a negative impact on grasses; for example, by periodically rotating cattle among pastures to avoid overgrazing, thereby facilitating recovery of grasses to increase their vegetative cover and fodder productivity. (3) A programme of reproduction in semi-captivity in situ in protected enclosures should be developed. If successful, jackrabbits could be released and reintroduced into the habitat. Such a programme could be certified as a Wildlife Use and Management Unit by the Department of the Environment and Natural Resources, to obtain legal use permits for a threatened mammal species, and economic support for programme development. (4) As part of the Wildlife Use and Management Unit a Communal Ecological Reserve could be established, to be administrated by community authorities, with universities playing a technical advisory role. Local protected areas have been shown to promote appropriation of territory by communities, and the patrimony of natural resources, and their management could be a viable method of conserving habitat and the Tehuantepec jackrabbit, as well as improving the quality of life of local residents. This could ensure the persistence of the Tehuantepec jackrabbit, with economic support from the government.

\section{Acknowledgements}

We thank Miguel Aquino, Roberto Gutiérrez, Leyberto Gutiérrez, Juan Antonio, Julieta Vargas, Felipe Barragán, and the people of the municipality of San Francisco del Mar for their valuable help during fieldwork, Ann Greenberg for editorial support, and the families of Antonio Gutiérrez and Gutiérrez Vázquez for housing our crew. We thank El Colegio de la Frontera Sur, the Chicago Zoological Society, the Lincoln Park Zoo Neotropic Fund, and Mexico's Consejo Nacional de Ciencia y Tecnología, and Secretaría de Medio Ambiente y Recursos Naturales for funding this research. Recommendations and comments from Martin Fisher and an anonymous reviewer improved this article. 


\section{Author contributions}

CL has provided funding for this study since 2001. She has monitored mammals in the field since 2001, and managed the mammal database. She supported the analysis of population density, and was the principal author. ECS has been monitoring mammals in the field since 2001. She managed the mammal database, reviewed satellite images and analysed changes in vegetation cover and land use, and assisted in writing the article. JBC has monitored mammals in the field since 2002. He managed the database, analysed density, and assisted in writing the article. DNG managed the database, analysed changes in vegetative cover and land use, and assisted in writing the article.

\section{References}

Altesor, A., Oesterheld, M., Leoni, E., Lezama, F. \& Rodríguez, C. (2005) Effect of grazing on community structure and productivity of a Uruguayan grassland. Plant Ecology, 179, 83-91.

Anderson, S. \& Gaunt, A. (1962) A classification of the white-sided jack rabbits of Mexico. American Museum Novitates, 2088, 1-16.

Arriaga, L. \& Gómez, L. (2004) Posibles efectos del cambio climático en algunos componentes de la biodiversidad de México. In Cambio Climático: una visión desde México (eds J. Martínez \&

A. Fernández), pp. 255-278. INE/SEMARNAT, Mexico.

B Ailey, T. (2005) Peninsula Snowshoe Hares on the Decline. Kenai National Wildlife Refuge. Refuge Notebook. U.S. Fish and Wildlife Service, Alaska, USA.

Bender, D.J., Contreras, T.A. \& Fahrig, L. (1998) Habitat loss and population decline: a meta-analysis of the patch size effect. Ecology, 79, 517-533.

Bocco, G.M., Mendoza, E. \& Masera, O. (2001) La dinámica del cambio del uso del suelo en Michoacán. Una propuesta metodológica para el estudio de los procesos de deforestación. Boletín Investigaciones Geográficas, 44, 18-38.

Buckland, S.T., Rexstad, E.A., Marques, T.A. \& Oedekoven, C.S. (2015) Distance Sampling: Methods and Applications. Springer, Heidelberg, Germany.

Carrillo-Reyes, A., Lorenzo, C., Naranjo, E.J., Pando, M. \& RiojA, T. (2010) Home range dynamics of the Tehuantepec jackrabbit in Oaxaca, Mexico. Revista Mexicana de Biodiversidad, 81 143-151.

Cervantes, F.A., Lorenzo, C., Farías, V. \& Vargas, J. (2008) Lepus flavigularis. In The IUCN Red List of Threatened Species 2008: e. T11790A3306162. Http://dx.doi.org/10.2305/IUCN.UK.2008.RLTS. T11790A3306162.en [accessed 25 April 2017].

Chapman, J.A. \& Ceballos, G. (1990) The cottontails. In Rabbits, Hares and Pikas, Status Survey and Conservation Action Plan (eds J. A. Chapman \& J.E.C. Flux), pp. 95-110. IUCN/SSC Lagomorph Specialist Group, Oxford, UK.

Chapman, J.A., Hockman, J. \& Edwards, W. (1982) Cottontails (Sylvilagus floridanus) and allies. In Wild Mammals of North America (eds J.A. Chapman \& G.A. Feldhamer), pp. 83-123. Johns Hopkins University Press, Baltimore, USA.

Chapman, J.A., Hockman, J.G. \& OJeda, C.M.M. (1980) Sylvilagus floridanus. Mammalian Species, 136, 1-8.

Daniel, A., Holechek, J., Valdez, R., Tembo, A., Saiwana, L., Fusco, M. \& Cardenas, M. (1993) Jackrabbit densities on fair and good condition Chihuahuan desert range. Journal of Range Management, 46, 524-528.
Davis, B. \& Schmidly, D.J. (1997) Black-tailed jackrabbit. In The Mammals of Texas - Online Edition. Texas Tech University. Http:// www.nsrl.ttu.edu/tmot1/Default.htm [accessed 24 April 2017].

Diffendorfer, J.E., Gaines, M.S. \& Holt, R.D. (1995) Habitat fragmentation and movements of three small mammals (Sigmodon, Microtus and Peromyscus). Ecology, 76, 827-839.

Drewry, J.J. \& Paton, R.J. (200o) Effects of cattle treading and natural amelioration on soil physical properties and pasture under dairy farming in Southland, New Zealand. New Zealand Journal of Agricultural Research, 43, 377-386.

Driessen, M. (1999) Effects of fire on the broad-toothed mouse, Mastacomys fuscus, and other small mammals in buttongrass moorlands of western Tasmania - preliminary findings. Conference proceedings. Australian Bushfire Conference, Albury, Australia.

Erlinge, S., Göransson, G., Högstedt, G., Jansson, G., Liberg, O., Loman, J. et al. (1984) Can vertebrate predators regulate their prey? The American Naturalist, 123, 125-133.

Fahrig, L. \& Paloheimo, J. (1988) Determinants of local population size in patchy habitats. Theoretical Population Biology, 34, 194-213.

FAO (Food and Agriculture Organization of the United Nations) (1996) Forest resources assessment 1990. Survey of tropical forest cover and study of change processes. FAO Forestry Paper, 130. FAO, Rome, Italy.

García, E. (1988) Modificaciones al sistema de clasificación climática de Köppen (para adaptarlo a las condiciones de la República Mexicana). Instituto de Geografía, Universidad Nacional Autónoma México, Mexico City, Mexico.

González, P.G., Briones-Salas, M. \& Alfaro, A.M. (2004) Integración del conocimiento faunístico del estado. In Biodiversidad de Oaxaca (eds A.J. García-Mendoza, M.J. Ordóñez \& M. Briones-Salas), pp. 449-466. Instituto de Biología, UNAM-Fondo Oaxaqueño para la Conservación de la NaturalezaWorld Wildlife Fund, Mexico.

HAYDEN, P. (1966) Seasonal occurrence of jackrabbits on Jackass Flat, Nevada. The Journal of Wildife Management, 30, 835-838.

Hoth, J., Velazquez, A., Romero, F.J., Leon, L., Aranda, M. \& BELL, D.J. (1987) The volcano rabbit-a shrinking distribution and a threatened habitat. Oryx, 21, 85-91.

Hunter, M. \& Cresswell, W. (2015) Factors affecting the distribution and abundance of the Endangered volcano rabbit Romerolagus diazi on the Iztaccihuatl volcano, Mexico. Oryx, 49, 366-375.

ineGi (Instituto Nacional de Estadística y Geografía) (2005) Carta de uso actual del suelo y vegetación. Serie III, Mexico.

inEGi (Instituto Nacional de Estadística y Geografía) (2012) Guía para la interpretación de cartografía. Uso del suelo y vegetación. Escala 1:2500oo. Series IV. Mexico.

Keith, L. (1990) Dynamics of snowshoe hare populations. In Current Mammalogy (ed. H.H. Genoways), pp. 119-195. Plenum Press, New York, USA.

Keith, L.B. \& Windierg, L.A. (1978) A demographic analysis of the snowshoe hare cycle. Wildlife Monographs, 58, 1-70.

KLOK, C. \& De Roos, A.M. (1998) Effects of habitat size and quality on equilibrium density and extinction time of Sorex araneus populations. Journal of Animal Ecology, 67, 195-209.

López, J.A., Lorenzo, C., Barragán, F. \& Bolaños, J. (2009) Mamíferos terrestres de la zona lagunar del Istmo de Tehuantepec, Oaxaca, México. Revista Mexicana de Biodiversidad, 80, 491-505.

López-Granados, E., Mendoza, M. \& Acosta, A. (2002) Cambio de cobertura vegetal y uso de la tierra. El caso de la cuenca endorreica del lago de Cuitzeo, Michoacán. Gaceta Ecológica, 64, 9-34.

Lorenzo, C., Cervantes, F.A., Barragán, F. \& Vargas, J. (2006) New records of the endangered Tehuantepec jackrabbit (Lepus 
flavigularis) from Oaxaca, Mexico. The Southwestern Naturalist, 51, 116-119.

Lorenzo, C., Carrillo-Reyes, A., Gómez-Sánchez, M., Velázquez, A. \& Espinoza, E. (2011) Diet of the endangered Tehuantepec jackrabbit, Lepus flavigularis. Therya, 2, 67-76.

Lorenzo, C., Carrillo-Reyes, A., Rioja-Paradela, T.M., de La Paz-Cuevas, M., Bolaños-Citalán, J. \& Álvarez-Castañeda, S.T. (2014) Estado actual de conservación de liebres y conejos en categoría de riesgo en México. Technical Report. Project HKo52. Comisión Nacional para el Conocimiento y Uso de la Biodiversidad, Mexico City, Mexico.

Lorenzo, C., Retana-Guiascon, O., Cervantes, F.A., Vargas, J. \& Portales, G.L. (2000) Status Survey of the Critically Endangered Lepus flavigularis. Final report to Chicago Zoological Society, El Colegio de la Frontera Sur. San Cristóbal de Las Casas, Chiapas, Mexico.

Lorenzo, C., Rioja, T.M., Carrillo, A. \& Cervantes, F.A. (2008) Population fluctuations of Lepus flavigularis (Lagomorpha: Leporidae) at Tehuantepec Isthmus, Oaxaca, Mexico. Acta Zoológica Mexicana, 24, 207-220.

Mas, J.F., Velázquez, A. \& Couturier, S. (2009) La evaluación de los cambios de cobertura/uso del suelo en la República Mexicana. Investigación Ambiental, 1, 23-39.

Meslow, E.C. \& Keith, L.B. (1968) Demographic parameters of a snowshoe hare population. The Journal of Wildlife Management, 32, 812-834.

Nájera, O., Bojórquez, J.I., Cifuentes, J.L. \& Marceleño, S. (2010) Cambio de cobertura y uso del suelo en la cuenca del río Mololoa, Nayarit. Revista Biociencias, 1, 19-29.

Ortiz, P., Hernández, J.R. \& Figueroa, J.M. (2004)

Reconocimiento Fisiográfico y geomorfológico. In Biodiversidad de Oaxaca (eds A.J. García-Mendoza, M.J. Ordóñez \&

M. Briones-Salas), pp. 43-54. Instituto de Biología, UNAM-Fondo Oaxaqueño para la Conservación de la Naturaleza-World Wildlife Fund, Mexico.

PARKer, G.R. (1984) Use of spruce plantations by snowshoe hare in New Brunswick. The Forestry Chronicle, 6o, 162-166.

Peralta-Rivero, C., Contreras-Servín, C., Galindo-Mendoza, M.G., Mas Caussel, J.F. \& Algara-Siller, M. (2014) Analysis of land use and land cover changes and evaluation of natural generation and potential restoration areas in the Mexican Huasteca region. Open Journal of Forestry, 4, 124-135.

Portales-Betancourt, G., Hernández, L., Laundré, J. \& Cervantes, F.A. (2012) Reproducción y densidad de la liebre cola-negra (Lepus californicus) en relación a factores ambientales, en la Reserva de la Biosfera Mapimí, Desierto Chihuahuense. Therya, 3 , 171-183.

Rioja, T., Lorenzo, C., Naranjo, E., Scott, L. \& Carrillo-Reyes, A. (2011) Breeding and parental care in the endangered Tehuantepec jackrabbit (Lepus flavigularis). Western North American Naturalist, $71,56-66$.

Rioja-Paradela, T., Carrillo-Reyes, A. \& Lorenzo, C. (2012) Análisis de población viable para determinar el riesgo de extinción de la liebre de Tehuantepec (Lepus flavigularis) en Santa María del Mar, Oaxaca. Therya, 3, 137-150.

Rizo-Aguilar, A., Delfín-Alonso, C., González-Romero, A. \& Guerrero, J.A. (2016) Distribution and density of the zacatuche rabbit (Romerolagus diazi) at the Protected Natural Area "Corredor Biológico Chichinautizin". Therya, 7, 333-342.
Rizo-Aguilar, A., Guerrero, J.A. Hidalgo-Mihart, M.G. \& GonZÁlez-Romero, A. (2015) Relationship between the abundance of the Endangered volcano rabbit Romerolagus diazi and vegetation structure in the Sierra Chichinautzin mountain range, Mexico. Oryx, 49, 360-365.

Rzedowski, J. (2006) Vegetación de México. Comisión Nacional para el Conocimiento y Uso de la Biodiversidad, Mexico.

Salvatori, V., Egunyu, F., Skidmore, A.K., De Leeuw, J. \& Van GiLs, H.A.M. (2001) The effects of fire and grazing pressure on vegetation cover and small mammal populations in the Maasai Mara National Reserve. African Journal Ecology, 39, 200-204.

Sántiz, E.C. (2002) Distribución y abundancia de la liebre endémica Lepus flavigularis y el conejo castellano Sylvilagus floridanus (Mammalia: Lagomorpha) en el Istmo de Tehuantepec. Oaxaca, México. Undergraduate thesis. Universidad de Ciencias y Artes de Chiapas, Mexico.

Sántiz, E.C., GonzÁlez-Romero, A., Lorenzo, C. Gallina-Tessaro, S. \& Cervantes, F.A. (2012) Uso y selección de asociaciones vegetales por la liebre de Tehuantepec (Lepus flavigularis) en Oaxaca, México. Therya, 3, 127-136.

Sántiz, E.C., Lorenzo, C., Carrillo-Reyes, A., Navarrete, D.A. \& Islebe, G. (2016) Effect of climate change on the distribution of a critically threatened species. Therya, 7, 147-159.

Silvano, F., Acquarone, C. \& Cucco, M. (2000) Distribution of the eastern cottontail Sylvilagus floridanus in the province of Alessandria. Hystrix, 11, 75-78.

Torres-Colín, R. (2004) Tipos de vegetación. In Biodiversidad de Oaxaca (eds A.J. García-Mendoza, M.J. Ordóñez \& M. Briones-Salas), pp. 105-117. Instituto de Biología, UNAM, Fondo Oaxaqueño para la Conservación de la Naturaleza-World Wildlife Fund, Mexico City, Mexico.

Vargas, J. (2000) Distribución, abundancia y hábitat de la liebre endémica Lepus flavigularis (Mammalia: Lagomorpha). MSc thesis. Universidad Nacional Autónoma de México, Mexico.

VARGAS, Z. (2001) Valoración de los vertebrados terrestres por huaves y zapotecas del Istmo de Tehuantepec, Oaxaca, México. MSc thesis. El Colegio de la Frontera Sur, San Cristóbal de Las Casas, Chiapas, Mexico.

Velázquez, A., Mas, J.F., Palacio, J.L., Díaz, J.R., Mayorga, S.R., Alcántara, C. et al. (2002) Patrones y tasas de cambio de uso del suelo en México. Gaceta Ecológica INE-SEMARNAT, 62, 21-37.

Villa, R.B. \& Cervantes, F.A. (2003) Los Mamíferos de México. Instituto de Biología, Universidad Nacional Autónoma de Mexico and Grupo Editorial Iberoamérica, Mexico.

\section{Biographical sketches}

Consuelo Lorenzo is interested in the molecular systematics, taxonomy and conservation of lagomorphs and tropical rodents and has been monitoring populations and habitat of the Tehuantepec jackrabbit Lepus flavigularis for 20 years. EUGENIA SÁNTIZ studies the ecology and effects of global climate change on the distribution of threatened mammals, and the conservation and management of the Tehuantepec jackrabbit and its habitat. JORGE BOLAÑOS-CitALÁn's work is focused on the conservation and management of tropical mammals, especially bats and rodents. Dario Navarrete-Gutiérrez studies changes in distribution of mammals, as well as consequences of land-use changes. 